\title{
Starting Over: The Midlife Entrepreneur
}

Kimberly Eddleston (Northeastern University)

\section{KEYWORDS: Entrepreneurship.}

Midlife is traditionally a time for traveling or playing more golf -- but not for mid-lifers who decide to leave the security of a steady paycheck for the uncertain life of an entrepreneur. Just ask former police officer Steven Mould, who started his high-end professional-quality knife company, Flint \& Flame, when he was close to age 50. In this interview with EIX's Kim Eddleston, Mould and his partner Lisa Lazure talk about the challenges of launching a new business at a time when many people are thinking about winding down. Mould admits he had more downtime and played more golf when he was a policeman, but both he and Lazure say they are energized by the chance to build something new, even if it means seven-hour days. Their insights will be useful for anyone thinking of starting a business in midlife.

\section{Read More on Older Entrepreneurs}

How Do You Know When It's Safe To Quit Your Day Job?(https://eiexchange.com/content/252-how-do-youknow-when-its-safe-to-quit-your-day-job)

How New Solo Entrepreneurs Can Think Through Their Finances(https://familybusiness.org/content/How-newsolo-entrepreneurs-can-think-through-the)

Educating the Unintended Entrepreneur (https://eiexchange.com/content/344-educating-theunintended-entrepreneur) 